\title{
BEACH FEEDING CAPACITY OF RIVERS AND LAGOONS OF THE SOUTHWEST COAST OF SRI LANKA
}

\author{
U. WEERAKKODY, \\ Department of Geography, University of Ruhuna, Matara.
}

$\begin{array}{ll}\text { (Date of receipt } & : \quad 16 \text { October 1992) } \\ \text { (Date of acceptance } & : \quad 20 \text { Febriary 1993) }\end{array}$

\begin{abstract}
Assessing the feeding capacity of rivers and lagoons is of vital importance to coastal engineering and protection activities. Previous studies on assessing the feeding capacity have been based on arbitrary values of sediment yield of drainage systems and assumptions on littoral transportation of material. In this study, a method is proposed to calculate the beach feeding capacity of rivers and lagoons on the basis of two factors; (a) the beach width, and (b) the feeding distance which is defined as the distance from the mouth of the drainage to the point where the beach width in front of the drainage takes half of the value. The method is tested using short-term accumulation of the beaches and long-term changes of the coastline of SW Sri Lanka. It is argued that the beach width can be used to assess the feeding capacity of rivers and lagoons of the coast without requiring discharge rate or information on other morphological phenomena.
\end{abstract}

\section{INTRODUCTION}

Beaches are fed by materials derived from rivers, lagoons and from terrace and cliff erosion. Most depositional beaches are devoid of natural cliffs, especially in the humid tropics. ${ }^{1}$ The sediment they receive may be derived from very distant sources or from adjacent rivers and lagoons. If material loaded on to the beaches is not removed by beach drifting, longshore currents, etc., or by man, the load may remain giving rise to wide luxurious beaches. If the materials are concurrently removed the beaches are narrowed and lead to intrusion of the swash zone into the immediate hinterland of the beach. Erosion then washes away valuable land and damages properties as in the Western and Southwestern coasts of Sri Lanka. The budget of littoral sediments which control the beach accumulation or degradation is of great importance in the study of coastal protection work, and has been analysed theoretically by many. ${ }^{2}$ Bowen and Inman, ${ }^{2}$ for example, have separated the sources and agents of materials (see Table 1).

In humid tropical coasts, rivers and lagoons are the most important agents on the credit side. Soil erosion and human activities in upper catchments supply much more material to beaches. The materials derived from slopes are partly deposited in rivers and lagoonal beds and the rest transported to the shelf or beyond. Some of the deposited materials in river beds and on beaches are mined for construction work. Mining activities on active river beds and beaches remove sands which are an essential part of a morphologic system and such activities may cause severe degradation of a coast. 
Table 1 : The budget of littoral sediments

\begin{tabular}{lll}
\hline Credit & Debit & Balance \\
\hline $\begin{array}{l}\text { Longshore transport } \\
\text { into area }\end{array}$ & $\begin{array}{l}\text { Longshore transport } \\
\text { out of area }\end{array}$ & Beach deposition or erosion \\
River transport & Wind transport & \\
Sea cliff erosion & Offshore transport & \\
$\begin{array}{l}\text { Onshore transport } \\
\text { Biogenous deposition }\end{array}$ & Deposition of sediments \\
$\begin{array}{l}\text { Wind transport onto } \\
\text { beach }\end{array}$ & Mining \\
Beach nourishment & \\
\hline
\end{tabular}

Assessing beach feeding capacity of rivers and lagoons has vital importance for policy decisions, planning and management of coastal zones. Therefore, several attempts have been made to assess the beach feeding capacity of rivers and lagoons of Sri Lanka for decades. However, these have not achieved desired results. The feeding capacity of rivers and lagoons has been commonly assessed by calculating discharge rates of the system (credit) and by giving arbitrary values at the debit side because measurement of the amount removed and deposited is somewhat difficult to assess in the field. Zeper, ${ }^{3}$ for example, tried to calculate the material gained by beaches on the basis of the discharge rate of coastal erosion which in turn was based arbitrary values of material deposited and removed. Swan (unpublished) who made an attempt to analyse the sand budget of the SW coast ultimately reasoning that 'sand distribution along the coast does not accord fully with expectations indicated by catchment size and discharge rates, mainly because of littoral transportation and deposition within and beyond the shorelines adjacent to the catchment concerned'.

In this study, it is proposed that the balance of the budget is indicated by the width of a beach. Beach deposition is the ultimate result of the credit and debit sides of the material budget and therefore, it can be called the balance. If the other factors of the credit side such as longhore transportation, biogenous deposition, wind transport and beach nourishment are assumed to be constant, the beach deposition or the balance of material budget is the result of the amount which has been brought by the adjacent rivers and lagoons of a coast. This is indicated by the existing beach width or by the volume of beach. The volume of beach cannot be quantitated for former periods because data for such periods are not available. If the beach width is taken as the indicator, it can be measured from sequential aerial photographs for former periods 
and the data can be used to analyse the temporal aspect of the problem. In this study, beach feeding capacity of the rivers and lagoons of the SW coast of Sri Lanka is assessed by using existing beach width measured in the field and beach width measured from sequential aerial photographs as the indicator of the material budget.

\section{STUDY AREA}

The area considered in the study is the SW coast which stretches from Ambalangoda to the Devundara headland (Figure 1 ). The SW coast is located in the wet zone of the island, and receives a rainfall that exceeds $1905 \mathrm{~mm}$ (75 inches) annually. ${ }^{4,5}$ The period between May and August is the period of the SW monsoon which gives rise to rough seas with significant effects on the beach profile of the SW coast. High waves wash the beaches which are built up during the intermonsoonal period, and transport beach materials along the shore. The velocity of the longshore currents increases and, in association with the rough waves created by the SW monsoon, beach drifting causes large-scale longshore transportation of material. During the intermonsoonal period the beach profile is re-built .

The drainage of the rivers, streams and lagoons of the SW coastal zone is dominated by monsoon rains. The peak discharge of the perennial rivers (with ample sediment load) is during the monsoonal period. The most important perennial rivers that contribute material to the shore are the Gin Ganga, falling $13 \mathrm{~km}$ to the north of Galle, the Nilwala Ganga in Matara and the Polwatu Ganga in Weligama bay.

Lagoons are widespread but their contribution to the discharge and sediment yield is very limited (see Table 2). The outfall of the Madampe lagoon, situated at Hirewatta to the south of Ambalangoda is controlled by a bund so as to protect paddy fields from saline water intrusion. The mouth of the Telwattaganga lagoon has been cut-off from the sea by the railway. The Hikkaduwaganga, Rathgama and Koggala lagoons also have their outfalls blocked by man-made structures such as bridges, groynes, etc. If a dam is constructed at the mouth of a lagoon, sand and silt load brought by lagoonal water is barricaded and deposited along the upstream side. This is the case of poor beaches developed at the mouth. In a similar manner, bridges, railway lines, groynes interfere with the free movement of sediment load and result in narrow beaches in both sides of the lagoonal mouth. Lagoons are rare east of the Weligama bay. Only the Garanduwa lagoon situated at Talaramba and the Devundara lagoon situated at Rassandeniya are the only exceptions but their surface area is negligible compared to the other lagoons (Table 2).

Human interference is characterized by the construction of dams, levees, reservoirs, etc., coastal engineering structures at river and lagoonal mouths. Construction of artificial levees reduces the sediment yield of rivers and lagoons by 


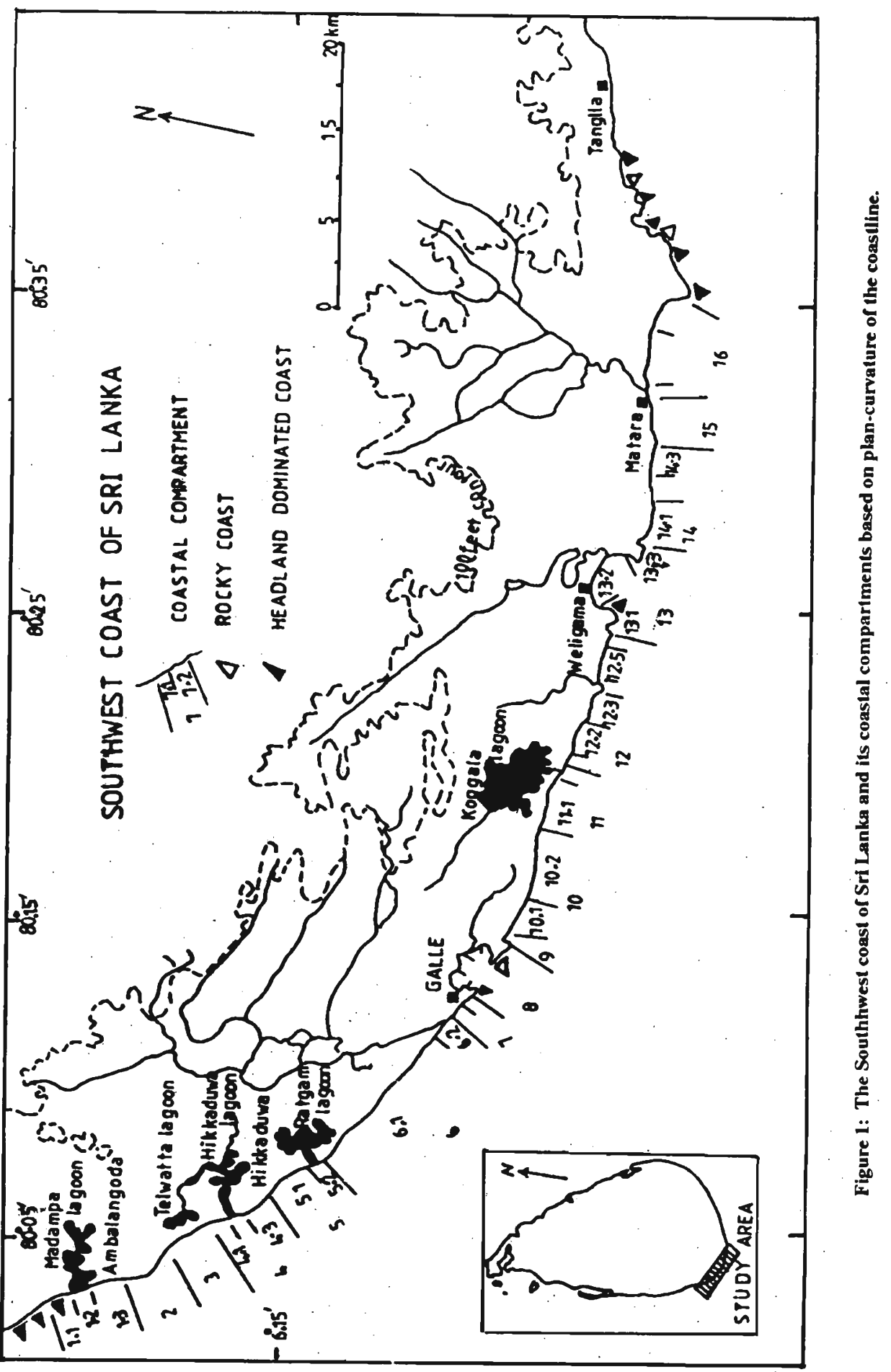


means of interference with the run off. Reservoirs gain a part of the sediment load which should be unloaded to the nearby coast. Unfortunately, data are not available on the effects of human interference on sediment load and further investigation is needed on this aspect on beach feeding capacity of rivers and lagoons.

Table 2 : The drainage system of the SW coastal zone

\begin{tabular}{|c|c|c|c|c|c|}
\hline \multirow{2}{*}{$\begin{array}{l}\text { Name of the } \\
\text { river/lagoon }\end{array}$} & \multirow{2}{*}{$\begin{array}{l}\text { Basin } \\
\text { area } \mathrm{m}^{2}\end{array}$} & \multicolumn{2}{|c|}{ Discharge } & \multirow[b]{2}{*}{ Annual } & \multirow{2}{*}{$\begin{array}{l}\text { Human inter- } \\
\text { ference*** }\end{array}$} \\
\hline & & Maha* & Yala** & & \\
\hline $\begin{array}{l}\text { Maduganga } \\
\text { lagoon }\end{array}$ & 23 & 63 & 74 & 134 & $\begin{array}{l}\text { groynes, sand bar } \\
\text { controlling walls }\end{array}$ \\
\hline $\begin{array}{l}\text { Madampe } \\
\text { lagoon }\end{array}$ & 35 & 95 & 110 & 205 & $\begin{array}{l}\text { controlling walls, } \\
\text { sand bar control }\end{array}$ \\
\hline $\begin{array}{l}\text { Telwattaganga } \\
\text { lagoon }\end{array}$ & 20 & 53 & 67 & 120 & not controlled \\
\hline Gin Ganga & 360 & 743 & 816 & 1150 & $\begin{array}{l}\text { artificial } \\
\text { levees in } \\
\text { some parts }\end{array}$ \\
\hline Koggala lagoon & 25 & 63 & 74 & 137 & not controlled \\
\hline Polwatu Ganga & 91 & 125 & 130 & 255 & partially \\
\hline Nilwala Ganga & 375 & 625 & 585 & 1210 & $\begin{array}{l}\text { controlling } \\
\text { measures are } \\
\text { being taken }\end{array}$ \\
\hline
\end{tabular}
*** added by the author. Maha = the period of cultivation between November and February. **Yala =
the period of cultivation between May and September. Source : Arumugam.

\section{Continental shelf}

The continental shelf of the SW coast becomes gradually narrow from North to South. The width of the northern area decreases by half $(12 \mathrm{~km})$ near Ahangama and $4.5 \mathrm{~km}$ near Devundara. The depth values also gradually decrease from North to South $<64 \mathrm{~m}$ at Dodanduwa, $<66 \mathrm{~m}$ at Ahangama, $<60 \mathrm{~m}$ at Devundara. ${ }^{5}$

The sediments of the offshore area of the SW coast consist of terrigenic materials, and are well or moderately well sorted by coastal or marine processes. The degradation of the coastline which supplies the sediment to the sea bed is shown by 
the composition of the materials which is mostly terrigenic. If offshore materials are redeposited on the beaches of the SW coast, no severe degradation may be expected along the coastline. The lack of redeposition of materials on the SW coast is due to two reasons;

1) The relatively narrow sea bed of the region does not favour the accumulation of materials ready for subsequent transportation towards the beaches.

2) Beachrock along the $S W$ shoreline restricts lateral longshore transportation of materials and thus provide only a low supply of materials to the beaches.

\section{METHODS}

As a preliminary step, the study area was divided into coastal compartments using plan-curvature types such as concave, convex, irregular and straight, etc. These coastal compartments were given specific numbers (Figure $1 \&$ Table 3 ). The mean beach width of each compartment was measured at $1 / 2 \mathrm{~km}$ intervals from the oldest available aerial photographs of Sri Lanka.

As can be observed in the field and from aerial photographs the beach is very broad in front of river mouths and outfalls of lagoons due to the excess supply of materials. The width of beaches gradually narrows towards the sides of the river mouths and outfalls of lagoons, indicating decreasing supply of materials. However, no clear boundary can be drawn between the effective areas of the river mouths and outfalls of lagoons. Therefore, the boundaries of the effective areas were drawn where the beach width is half of the width in front of the river mouth or outfall. This distance is referred to as the 'the feeding distance' of the river mouth or outfall (Figure 2). Using the feeding distance of each river/lagoon, the beach compartments fed by an excess of sediment could be recognized. The beaches covered by the feeding distance are referred to here as 'river-fed beaches' (Figure 2).

Comparison of the values of beach width of 1956 with that of 1987 reveals the feeding capacity of rivers and lagoons in the study area. If the coastal compartment shows less change in beach width between 1956 and 1987, it is an indication of being well-fed by a nearby river or lagoon. Since the above changes of beach width refer to short-term changes, longer-term changes of the coastline between 1905 and 1987 were studied using old topographical maps and recent sequential aerial photographs. The data on coastline changes were from a previous study of the author. ${ }^{8}$ The maps and aerial photographs used are : 1) All maps published in the period between 1905 and 1917, 2) The maps published during the period between 1932 and 1934, 3) The last one-inch map which was revised and published in 1972, 4) The 16 chain charts compiled in the year of 1921, 1932, 1933 and 1943. 


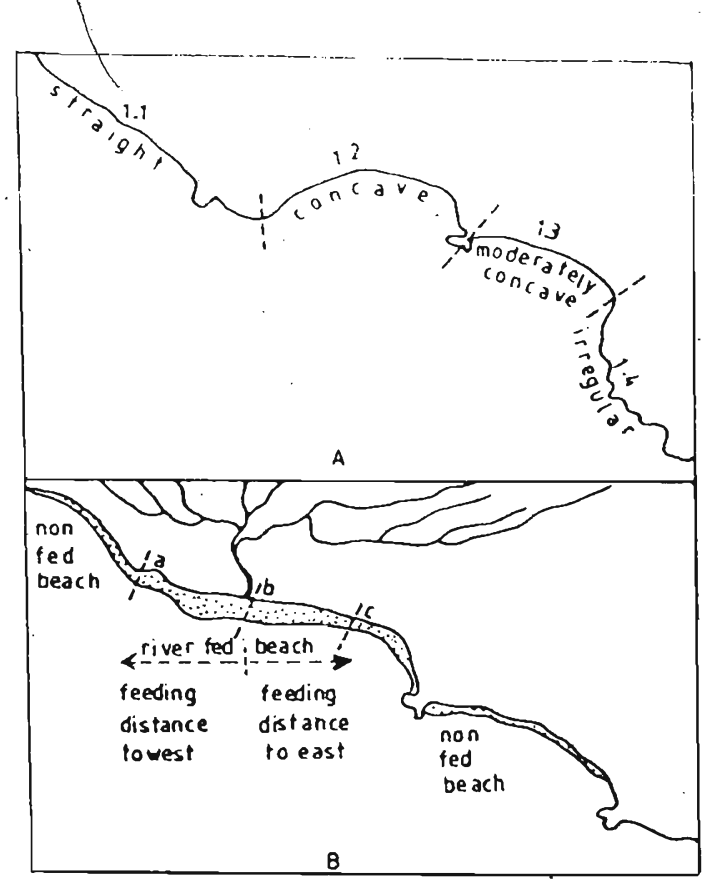

Figure 2: (A) Illustrates the method to divide the coastline of the study area into compartments based on plan-shape of the coastline, and (B) lllustrates method to measure the feeding distance. (b) is the wide beach in front of the river mouth, while (a) or (c) represents half of the value of the beach width in front of the river mouth or value (b). The feeding distance therefore can be defined as the distance from the mouth of the drainage to the point where the beach width in front of the drainage takes half of the value.

The sequential aerial photographs used date from 1956, 1973/74 and 1987, and have a scale of 1:40,000,1:25,000 and 1:10,000 respectively. As the years represented by the aerial photographs of 1956 and 1973/74 are observed by the period represented by the topographical maps of 1934 and 1972, the information given in the 1956 and 1973/74 aerial photographs were neglected. The absolute changes of the coastline during the last 14 years (between 1973 and 1987) were studied comparing the photographs of the two younger aerial photograph coverage.

As both the 16 chain charts and the one-inch maps had to be utilized for the quantitative measurements of coastline changes, they were compiled into two maps on the same scale. The one-inch maps used were mechanically enlarged using Pantograph at a scale of $2.6 \mathrm{~cm}$ to $406 \mathrm{~m}$ (one inch to quarter mile). The 16 chain charts were blown upto the same scale. Two outline maps of the coastline compiled based on the aerial photographs of 1973 and 1987 were also blown upto the same scale.

A series of sequential maps thus was compiled following this procedure. These maps cover a 67 year period (1905 to 1972) of coastline changes. Projecting the maps 
of 1905 on to the map of 1933, for example, gives a map showing the changes that occurred in the period between 1905 and 1933. Using a planimeter, the area lost and gained during this period were measured, with the help of the differences between two maps. The data obtained were grouped into river-fed beaches and non-fed beaches on the basis of the above mentioned procedure. The coastline changes during the period relating to the two categories of beaches were compared to assess the long-term effects of rivers and lagoons and to reassess the results of the changes of beach width.

\section{RESULTS}

The coastal compartments which are outside the feeding distances of each river/lagoon can be considered as the beaches which are not fed by river or lagoon of the SW coast. Table 3 shows the two categories of beach with their mean beach width of 1956 and 1987. The width of the river-fed beaches is broader as expected than those of non-fed beaches. The validity of such a separation can be tested if, they are correlated to each other. The mean beach widths of 1956 and 1987 were plotted against each other and the results are shown in the scatter diagram of Figure 3.

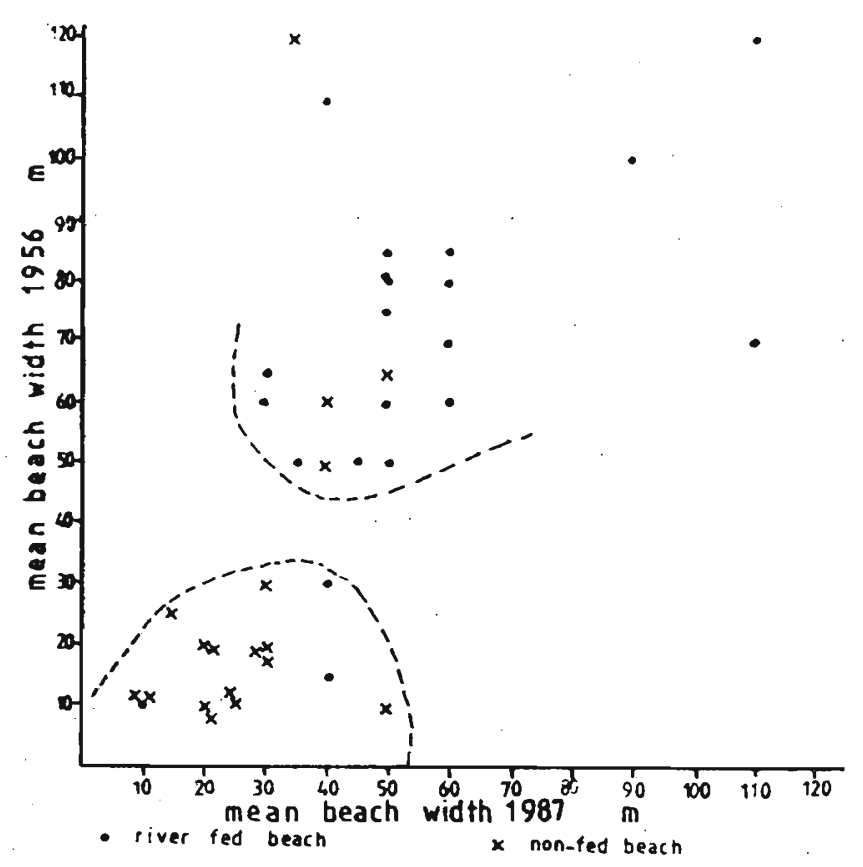

Figure 3: Scatter diagram of the beach width in 1956 and 1987 . The clustering pattern of river fed beaches and non-fed beaches helps to separate them. Note that most of the river fed beaches cluster in the upper area while the non-fed beaches concentrate in the lower portion. 
Accordingly, the river-fed beaches and non-fed beaches are clearly separated, except for a few compartments. The non-fed beaches 14.2, 14.3, 8.1 and 8.2 stand in the category of river fed beaches. The 8.1 and 8.2 compartments are bay-mouth beaches (Figure 1). Therefore, they should stand in a zone of prograding beaches as found in river-fed beaches. However, 14.2 and 14.3 cannot be explained in this way. Similarly, three river-fed beaches of 4.3 and 5.2 are located in the category of non-fed beaches. The beaches of 4.3 and 5.2 are located in the nodal area of the longshore drift of the SW coast. ${ }^{9}$ Therefore, they are washed by waves reaching perpendicular to the shore.

Table 3 : River-fed and non-fed beaches of the SW coast

\begin{tabular}{|c|c|c|c|c|c|}
\hline \multicolumn{3}{|c|}{ River-fed beaches } & \multicolumn{3}{|c|}{ Non-fed beaches" } \\
\hline $\begin{array}{l}\text { No of the beach } \\
\text { compartment }\end{array}$ & $\begin{array}{l}\text { Mean } \\
\text { beach } \\
\text { width } \\
1956\end{array}$ & $\begin{array}{l}\text { Mean } \\
\text { beach } \\
\text { width } \\
1987\end{array}$ & $\begin{array}{l}\text { No of the beach } \\
\text { compartment }\end{array}$ & $\begin{array}{l}\text { Mean } \\
\text { beach } \\
\text { width } \\
1956\end{array}$ & $\begin{array}{l}\text { Mean } \\
\text { beach } \\
\text { width } \\
1987\end{array}$ \\
\hline 1.1 & 80 & 60 & 2 & 20 & 30 \\
\hline 1.2 & 60 & 60 & 3 & 65 & 50 \\
\hline 1.3 & 50 & 45 & 8.1 & 60 & 40 \\
\hline 4.1 & 80 & 50 & 8.2 & 120 & 30 \\
\hline 4.2 & 50 & 50 & 8.4 & 10 & 10 \\
\hline 4.3 & 10 & 10. & 8.5 & 10 & 10 \\
\hline 5.1 & 85 & 60 & 9 & 20 & 30 \\
\hline 5.2 & 30 & 40 & 10.1 & 30 & 30 \\
\hline 6.1 & 75 & 50 & 10.2 & 40 & 30 \\
\hline 6.2 & 70 & 100 & 12.2 & 20 & 30 \\
\hline 7.1 & 80 & 50 & 12.3 & 10 & 20 \\
\hline 7.2 & 110 & 30 & 12.5 & 10 & 20 \\
\hline 8.3 & 85 & 50 & 12.6 & 25 & 15 \\
\hline 11.1 & 120 & 110 & 13.1 & 10 & 25 \\
\hline 11.2 & 50 & 35 & $13.3^{\circ}$ & 10 & 25 \\
\hline 12.1 & 15 & 40 & 14.2 & 20 & 20 \\
\hline 12.4 & 10 & 50 & 14.3 & 50 & 40 \\
\hline 13.2 & 100 & 90 & 15 & 20 & 20 \\
\hline 14.1 & 80 & 60 & & & \\
\hline 16.1 & 60 & 50 & & & \\
\hline 16.2 & 60 & 30 & & & \\
\hline 16.3 & 60 & 30 & & & \\
\hline
\end{tabular}

\footnotetext{
"River-fed and non-fed beches have been defined in the text.
} 
The conclusion derived from the above discussion is that river-fed beaches have prograded while non-fed beaches have degraded. If these results are confirmed by longer-term changes, the separation of river-fed beaches from the non-fed beaches can be justified. The data on the coastline changes for the period between 1905 and 1987 were used to assess the average net degradation/progradation of river-fed and non-fed beaches. Figure 4 shows that the river-fed beaches (except the area between Ambalangoda and Hikkaduwa or beach compartments 1.1, 1.2, 1.3, 4.2 and 4.3) have maintained a considerable rate of progradation, while the non-fed beaches (except for a few segments such as the western headland of Galle, the Talpe coast and Mirissa headlands or beach compartments 8.1,10.2, and 13.3) have degraded large land areas during the period.

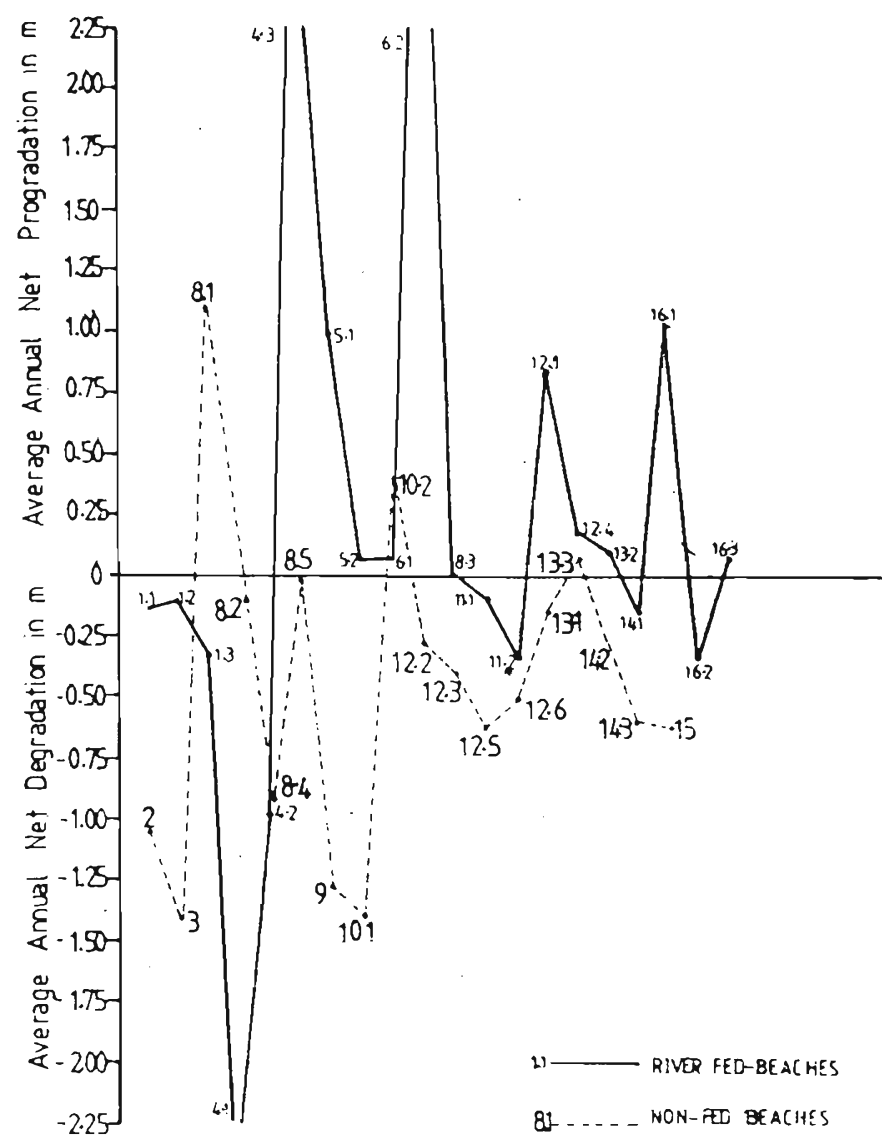

Figure t: Average net degradation/progradation of river fed beaches and non-fed beaches. Most of the river fed beaches stand in the progradation zone while the non-fed beaches occur in the degradation zone except three compartments. (Average annual net degradation has been obtained by substracting the progradation values of the beach compartments). 
Table 4: Beach feeding capacity of the drainage system of the SW coast

\begin{tabular}{lcccc}
\hline $\begin{array}{l}\text { Drainage } \\
\text { system }\end{array}$ & $\begin{array}{l}\text { Towards the } \\
\text { north/north } \\
\text { west }\end{array}$ & $\begin{array}{l}\text { Feeding distance } \\
\text { Number } \\
\text { of the } \\
\text { compart } \\
\text { ment }\end{array}$ & $\begin{array}{l}\text { Towards the } \\
\text { south/south } \\
\text { east }\end{array}$ & $\begin{array}{l}\text { Number } \\
\text { of the } \\
\text { beach } \\
\text { compart } \\
\text { ment }\end{array}$ \\
\hline Madampe lagoon & 340 & 1.2 & 640 & 1.2 \\
Hikkaduwa lagoon & 1800 & $4.1,4.2$ & 480 & 4.3 \\
Ratgama lagoon & 3520 & $5.1,5.2$ & 3280 & 6.1 \\
Gin Ganga & 3480 & 6.1 & 480 & 6.2 \\
Osangoda lagoon & 520 & 7.1 & 1200 & 7.2 \\
Galuganga (lagoon) & 1080 & 8.3 & 120 & 8.3 \\
Hikkaduwa lagoon & 4560 & 11.1 & 880 & $11.1,11.2$ \\
Midigama ela & 880 & 12.4 & 560 & 12.4 \\
Polwatu Ganga & 4000 & 13.2 & 0 & - \\
Garanduwa lagoon & 680 & 14.1 & 600 & 12.4 \\
Nilwala Ganga & 720 & 16.1 & 2720 & $16.2,16.3$ \\
\hline
\end{tabular}

* Feeding distance is defined as the distance from the mouth of the drainage to the point where the beach width in front of the drainage takes half of the value.

* The orientation changes as northwest/north at the Galle beach.

The orientation changes as south/southeast at the Galle beach.

\section{DISCUSSION}

The tendancy has been for the beach feeding capacity of rivers and lagoons of Sri Lanka to be assessed taking into consideration hypothetical values of the amount of sand and silt discharged into the coast. Such an approach is correct if the whole volume of materials brought by the rivers and lagoons is calculated and the debit side of the sand budget is estimated. However, such data relevant to the SW coast or the rest of Sri Lanka have not been available. Therefore, the volume of beach materials has been calculated as a proportion of water load discharged by the rivers and lagoons in some studies. Zeper ${ }^{3}$ points out that with regard to the sand and the silt-load respectively of $10^{-5}$ and $10^{-4}$ times the discharge of water might give an indication of the quantities involved. However, data based on such assumptions cannot be treated as real values because velocity of rivers, the human activities in the upper catchments which accelerate or decelerate sediment yield, etc., may fluctuate giving different estimates of silt and sand-loads to the beaches. Since the material load brought to the beaches is removed at different rates due to erosion, spatial changes to the rate of 
accumulation cannot be calculated in this way. Therefore, the present rate of deposition which is represented by the beach width takes as a good indicator of beach accumulation. Using the mean beach width, the feeding capacity can be assessed concerning the feeding distance of the nearby river/lagoon which is defined here as the distance from the mouth of the drainage to the point where the beach width in front of the drainage takes half of the value.

Comparison of data pertaining to beach width of 1956 and 1987 reveals that the beaches within the feeding distance of rivers and lagoons of the study area have been prograded while those without have degraded. Many coastal compartments within the feeding distance of rivers and lagoons of the SW coast have prograded except for a few compartments. The beaches located at places such as a mouth which enhances accumulation show similar effects to those given by rivers and lagoons. The beaches situated at nodal areas of the longshore drift also have low accumulation rates.

The short-term changes of the beaches prove that the river-fed beaches and non-fed beaches are separated clearly by their accumulating rate. The feeding distance and beach width are useful indicators of accumulation as far as concerned the period between 1956 and 1987. The analysis of the long-term changes of the coastline shows that the river-fed beaches have maintained a considerable rate of progradation, while non-fed beaches have lost large land areas during the study period. On this basis it can be deduced that the criteria used to assess the beach feeding capacity are valid for the study of coastline changes in the long-term perspective. Data presented in Figure 4 indicate that there is a general trend of balancing between coastal degradation and progradation when moving from southwest (Ambalangoda) to the south (Devundara). Causative factors for this trend cannot be acertained without ascertaining other factors such as the orientation of the coast, littoral currents, indentedness of the coastline, etc. which control erosion and accretion of the SW coast. The beaches located at protective places such as bay-mouth, huge promontories, headlands enhance accumulation. In addition, the beach compartments within the category of non-fed beaches may have been under other unknown factors of degradation. More research into these factors together with beach feeding capacity based on the beach width and feeding distance will help in understanding the spatial pattern of progradation and degradation of the SW coast.

\section{Acknowledgement}

I am grateful to Prof. B. K. Basnayaka, University of Peradeniya for constructive comments and to Prof. H. Th. Verstappen, IGU for valuable suggestions. 


\section{References}

1. Bird E.C.F. (1969). Coasts. Massachusetts Institute of Technology Press, Massachusetts and London.

2. Komar P. D. (1976). Beach processes and sedimentation. pp. 265. Prentice Hall Inc. New York.

3. Zeper J. (1960). Sea erosion studies and recommendations on coast protection in Ceylon. Netherlands Bureau for International Technical Association. pp. 62. Ministry for Foreign Affairs, The Hague.

4. Cook E. K. (1950). Geography of Ceylon ( $2^{\text {nd }}$ ed.) pp. 163. Macmillan, Colombo.

5. Sirinanda K. U. (1979). Water balance types and water resources development in the dry zone of Sri Lanka. Joumal of Tropical Geography 49: 48-54.

6. Swan B. (1982). The coastal geomorphology of Sri Lanka, National Museum, Colombo.

7. Arumugam S. (1969). Water resources of Ceylon; its utilization and development. pp. 130. Water Resources Board, Colombo.

8. Weerakkody U. (1992). Changing Coastline of Southwest Sri Lanka. pp. 55. NARESA, Colombo,

9. Gerritsen F. (1974). Coastal engineering in Sri Lanka. Report on UN Mission, pp. 13. University of Hawaii, Honolulu. 